\title{
Spatiotemporal expression of alternatively spliced IGF-I mRNA in the rat costochondral growth plate
}

\author{
W-w Lin and A M Oberbauer \\ Department of Animal Science, University of California, Davis, California 95616, USA \\ (Requests for offprints should be addressed to A M Oberbauer)
}

\begin{abstract}
IGF-I acts as a local proliferation and maturation factor for chondrocytes in the growth plate. However, the expression of different alternative IGF-I mRNA classes in the growth plate has not been characterized. Using quantitative reverse transcription PCR, the abundance of each alternative IGF-I mRNA class in resting, proliferative and hypertrophic chondrocytes was measured in rat costochondral growth plates. Class $1 \mathrm{Ea}$ mRNA was the most abundant IGF-I transcript overall and was highly expressed in proliferative chondrocytes at 2 and 4 weeks of age; by 6 weeks, the majority of $1 \mathrm{Ea}$ mRNA expression had shifted to hypertrophic chondrocytes. Class $1 \mathrm{~Eb}$ mRNA was the second most abundant transcript and its
\end{abstract}

distribution was uniform across all the cell types at 2 weeks of age. The expression pattern changed with increasing age such that at 6 weeks a gradient existed with hypertrophic chondrocytes expressing higher levels of $1 \mathrm{~Eb}$ than resting chondrocytes. Class 2Ea mRNA was constitutively expressed at low levels across the growth plate at all ages, while class $2 \mathrm{~Eb}$ mRNA expression was negligible. The distribution of total IGF-I mRNA also shifted across growth plate cell types as the animals aged from 2 to 6 weeks. These findings suggest that IGF-I class $1 \mathrm{mRNA}$ plays the predominant role in the maturation of the growth plate.

Journal of Endocrinology (1999) 160, 461-467

\section{Introduction}

The growth of long bones is driven by the cellular activity of chondrocytes within the growth plate (Isaksson et al. 1987, Kember 1993). Small germinal chondrocytes in the resting zone enter the cell cycle and undergo successive mitotic divisions to form columns of chondrocytes in the proliferative zone. After leaving the cell cycle, differentiated chondrocytes hypertrophy and are gradually replaced by bone matrix. Therefore the rate of bone elongation is determined by chondrocyte performance during the progression from resting to proliferative to hypertrophic stages (Hunziker \& Schenk 1989).

Insulin-like growth factor-I (IGF-I) mediates the stimulatory effect of growth hormone $(\mathrm{GH})$ on longitudinal bone growth chondrocytes (Daughaday \& Rotwein 1989) by increasing the proliferation rate, matrix production and cell hypertrophy of growth plate chondrocytes (Isaksson et al. 1990, Hunziker et al. 1994). The source of IGF-I that regulates the chondrocyte performance is the circulating IGF-I produced in liver and the autocrine/paracrine IGF-I synthesized from the growth plate (Daughaday \& Rotwein 1989, Ohlsson et al. 1993). Although IGF-I mRNA has been detected in the proliferative and hypertrophic zones of rat growth plate by in situ hybridization (Nilsson et al. 1990), the method can neither quantify the abundance of
IGF-I mRNA nor distinguish among different classes of alternative IGF-I mRNA.

Rat tissue IGF-I mRNA is a heterogeneous array of transcripts resulting from different transcription start sites, alternative splicing and various polyadenylation sites (Bucci et al. 1989, Adamo et al. 1991, Hall et al. 1992). Transcription can start at either exon 1 or exon 2, which are exclusively spliced to exon 3. Exon 3, 4 and 6 are present in all transcripts, while exon 5 is alternatively spliced to exon 6. According to the presence of exon 1 (class 1 transcripts) or exon 2 (class 2 transcripts) and the presence (Eb form) or absence (Ea form) of exon 5 in the mRNA, the IGF-I transcripts are classified into class 1Ea, 1Eb, 2Ea and 2Eb mRNA (Fig. 1A) (Holthuizen et al. 1991). While these four classes of IGF-I mRNA display variations in developmental regulation, tissue specificity and GH responsiveness (Lowe et al. 1987, Adamo et al. 1989, Arkins et al. 1993), their relative abundance and developmental expression in the growth plate have not been characterized.

In this study, we investigated the distributional patterns of these alternative IGF-I mRNA transcripts in the costochondral growth plates of rats during postnatal development. We used percoll density fractionation to collect growth plate chondrocytes at various stages of differentiation (Oberbauer \& Peng 1995) and the 
A.

\begin{tabular}{|c|c|c|c|c|c|}
\hline \multirow[b]{2}{*}{ Class IEa } & \multicolumn{5}{|c|}{$\stackrel{1 F}{\rightarrow}$} \\
\hline & 1 & 3 & 4 & & 6 \\
\hline & \multicolumn{3}{|c|}{ If } & \multicolumn{2}{|c|}{$46 \mathrm{RR}$} \\
\hline \multirow[t]{2}{*}{ Class $1 \mathrm{~Eb}$} & 1 & 3 & 4 & 5 & 6 \\
\hline & $2 \mathrm{~F}$ & & & \multicolumn{2}{|l|}{$\frac{\pi}{5 R}$} \\
\hline \multirow[t]{2}{*}{ Class 2 Ea } & 2 & 3 & 4 & \multirow{2}{*}{\multicolumn{2}{|c|}{$4 / 3 R$}} \\
\hline & $2 \mathrm{H}$ & & & & \\
\hline Class $2 \mathrm{~Eb}$ & 2 & 3 & 4 & 5 & 6 \\
\hline
\end{tabular}

$\mathrm{B}$.

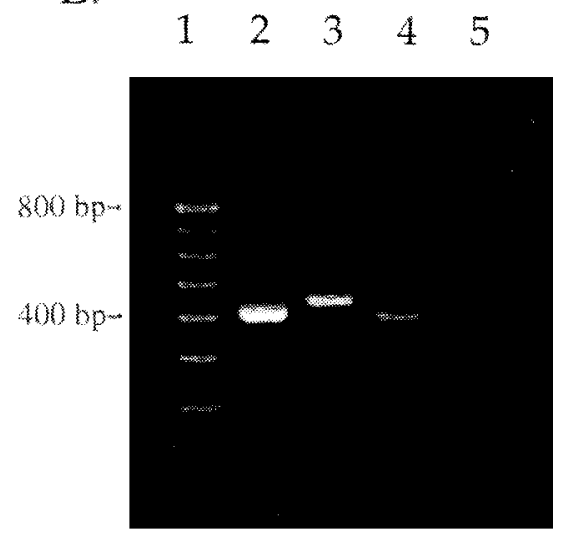

Figure 1 Detection of alternative IGF-I mRNA in the costochondral growth plate. (A) The four classes of IGF-I mRNA and locations of primers for RT-PCR amplification; exons are not drawn to scale and PCR primer sites are indicated by arrows. (B) Electrophoresis of amplified RT-PCR products from growth plate RNA. Lane 1, 100 bp DNA marker; lanes 2-4, 412, 446 and 393 bp DNA amplified from 1Ea, 1Eb and 2Ea mRNA respectively; lane 5, no detected DNA fragment amplified using the primer pair specific for 2Eb mRNA.

abundance of each class of alternative IGF-I mRNA was measured by quantitative reverse transcription (RT) PCR (RT-PCR).

\section{Materials and Methods}

\section{Growth plate chondrocyte fractionation}

Growth plate chondrocytes at various stages of differentiation were fractionated by discontinuous percoll gradient centrifugation using a protocol modified from that previously described (Oberbauer \& Peng 1995). Costochondral growth plates from six male SpragueDawley rats were dissected free of adherent tissue, cut to $2-3 \mathrm{~mm}$, pooled and predigested by incubation in Dulbecco's modified Eagle's medium (DMEM)/F12 (Gibco BRL, Grand Island, NY, USA) containing 0.05\% trypsin (JRH Biosciences, Lenexa, KS, USA), 0.5\% hyaluronidase (Worthington Biochemical, Freehold, NJ, USA) and $2 \%$ fetal bovine serum (FBS) (Gibco) at $37^{\circ} \mathrm{C}$ for $45 \mathrm{~min}$. The growth plates were then digested in DMEM/F12 containing $0.3 \%$ collagenase type II (Worthington) and $2 \% \mathrm{FBS}$ at $37^{\circ} \mathrm{C}$ for $5 \mathrm{~h}$. After the first $30 \mathrm{~min}$ of collagenase digestion, the media with released tissue debris and freed cells were discarded and fresh reagents added. Following the $5 \mathrm{~h}$ enzymatic digestion of the extracellular matrix, the freed cells were separated from tissue debris by filtration through a $70 \mu \mathrm{m}$ nylon cell strainer (Becton Dickinson, Franklin Lakes, NJ, USA) and collected from the filtrate by centrifugation at $200 \boldsymbol{g}$ for 5 min, washed in DMEM/F12 twice and resuspended in $1 \mathrm{ml}$ DMEM/F12 medium. Growth plate cells were layered on a discontinuous isotonic percoll (Pharmacia,
Piscataway, NJ, USA) gradient prepared by weight (densities of 1.0250, 1.0340, 1.0402, 1.0436 and $1.0526 \mathrm{~g} / \mathrm{ml}$ ) and centrifuged at $1875 \mathrm{~g}$ for $15 \mathrm{~min}$ in a swinging bucket rotor. Five cell fractions were formed after centrifugation: fraction 1 enriched with 90\% hypertrophic cells and 10\% proliferative cells; fraction 2 consisted of 30\% hypertrophic cells and 70\% proliferative cells; fraction 3 consisted of 5\% hypertrophic cells and 95\% proliferative cells; fraction 4 consisted of $75 \%$ proliferative cells and 25\% resting cells; fraction 5 consisted of $5 \%$ proliferative cells and 95\% resting cells (Oberbauer \& Peng 1995). Each of the five cell fractions was collected, washed with $10 \mathrm{ml}$ DMEM/F12 medium and centrifuged at $500 \mathrm{~g}$ for $10 \mathrm{~min}$. Total RNA from the resulting cell pellets was then prepared.

\section{RNA isolation}

For RNA isolation from the entire growth plate, costochondral growth plates of five 4-week-old male SpragueDawley rats were dissected free of adherent tissue and homogenized in $5 \mathrm{M}$ guanidinium thiocyanate, $17 \mathrm{mM}$ n-lauryl sarcosine, $25 \mathrm{mM}$ sodium citrate, $0 \cdot 1 \mathrm{M}$ 2-mercaptoethanol (Sigma Chemical Co., St Louis, MO, USA) (Chomczynski \& Sacchi 1987). For RNA isolation from fractionated chondrocytes, the cells from each of the five fractions were lysed in the guanidinium solution. Total RNA was then isolated either from the tissue homogenate or fractionated cell lysate (Chomczynski \& Sacchi 1987). Total RNA was quantified by spectrophotometric measurement of the absorbance at $260 \mathrm{~nm}$. The integrity of RNA was assessed by electrophoresis in a formaldehyde denaturing 1\% agarose gel. 
A

5'RE $\quad 1 F \quad 2 F \quad\left(80\right.$ base deleted IGF-I exon 3 and exon 4) 4/6R $5 R \quad 6 R \quad(A)_{20}$

395 base IGF-I cRNA

\section{B}

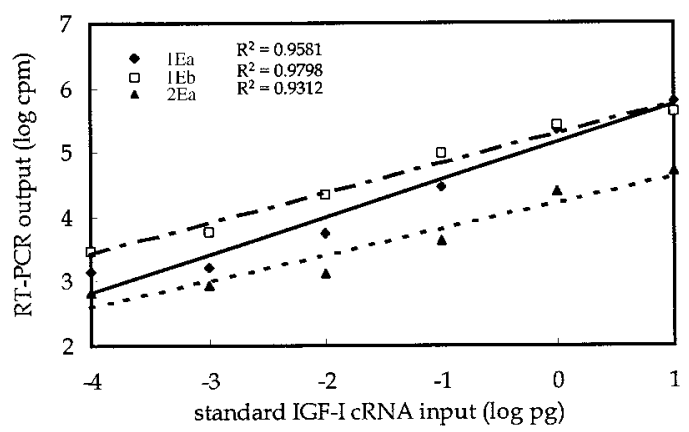

Figure 2 (A) Structure of IGF-I cRNA standard and (B) standard curves for the quantification of three classes of alternative IGF-I mRNA derived from amplification of the varying quantities of input cRNA.

\section{Quantitative RT-PCR analysis}

Synthesis of IGF-I cRNA standard To measure the absolute abundance of each class of IGF-I mRNA, an IGF-I cRNA (Fig. 2A) was synthesized as previously described (Lin \& Oberbauer 1998). This cRNA contains the primer sequence for each class of IGF-I mRNA (see below) and a polyA tail, therefore it can be reverse transcribed with oligo(dT) ${ }_{12-18}$ and PCR amplified with the same primer pair as endogenous IGF-I mRNA. Briefly, a 418 bp IGF-I DNA fragment was synthesized by oligonucleotide overlap extension PCR (Horton et al. 1989, Wang et al. 1989). This IGF-I synthetic DNA contained the T7 promoter sequence, primer $1 \mathrm{~F}$ sequence, $2 \mathrm{~F}$ sequence at the $5^{\prime}$ end, $(\mathrm{dA})_{20}$, primer $5 \mathrm{R}$ sequence, $4 / 6 \mathrm{R}$ sequence at the $3^{\prime}$ end and an $80 \mathrm{bp}$-deleted IGF-I exon 3 and exon 4 sequence in the middle. A 395 base cRNA was then synthesized by in vitro transcription of the 418 bp IGF-I synthetic DNA with T7 RNA polymerase (MEGAshortscript in vitro transcription kit, Ambion, Austin, TX, USA) (Heuvel et al. 1993). Because this IGF-I cRNA carried an $80 \mathrm{bp}$ deletion in the exon 3 sequence, the RT-PCR fragment amplified from this cRNA could be distinguished from the RT-PCR fragment amplified from endogenous IGF-I mRNA on a $2 \%$ agarose gel based on the size difference.

PCR primers and amplification of alternative IGF-I mRNA Amplification of each alternative IGF-I mRNA class was done using oligonucleotide primers designed from the published rat IGF-I cDNA sequence (Shimatsu \&
Rotwein 1987, Bucci et al. 1989, Hall et al. 1992) and as described (Lin \& Oberbauer 1998). The locations of the primers are shown in Fig. 1A. The exon 1 forward primer (1F) was paired with a reverse primer spanning the junction of exon 4 and 6 (4/6R) to amplify IGF-I class 1Ea, and class IEb was amplified with primer $1 \mathrm{~F}$ in conjunction with a reverse primer specific for exon 5 (5R). IGF-I class $2 \mathrm{Ea}$ was amplified using a forward primer specific for exon 2 (2F) and the 4/6R primer, while class $2 \mathrm{~Eb}$ was amplified using the primer pair $2 \mathrm{~F}$ and $5 \mathrm{R}$.

To determine what alternative forms of IGF-I were expressed in the growth plate, total RNA isolated from the entire growth plate was amplified at high cycle numbers. Briefly, $1 \mu \mathrm{g}$ total growth plate RNA was reverse transcribed into first strand cDNA in a $50 \mu \mathrm{l}$ reaction containing $1 \mu \mathrm{g}$ oligo $(\mathrm{dT})_{12-18}$, Moloney murine leukemia virus reverse transcriptase (MMLVRT) $1 \times$ buffer, $1 \mathrm{mM}$ dNTPs, 40 units RNasin and 300 units MMLVRTase (Promega, Madison, WI, USA) at $39^{\circ} \mathrm{C}$ for $60 \mathrm{~min}$, heated to $95{ }^{\circ} \mathrm{C}$ for $10 \mathrm{~min}$ and quenched on ice. PCR amplification was assembled in a $50 \mu \mathrm{l}$ reaction containing $2 \mu \mathrm{RT}$ reaction product, $30 \mathrm{pmol}$ each of forward and reverse primer, $1 \times$ Thermo buffer, $0.2 \mathrm{mM}$ dNTPs, $2.5 \mathrm{mM} \mathrm{MgCl} 2$ and 1.25 units Taq DNA polymerase (Promega). The reaction was cycled 38 times at $94{ }^{\circ} \mathrm{C}$ for $1 \mathrm{~min}, 60^{\circ} \mathrm{C}$ for $1 \mathrm{~min}$ and $72{ }^{\circ} \mathrm{C}$ for $1 \mathrm{~min}$. Twelve microliters of PCR product were electrophoresed on a $2 \%$ agarose gel to check the specificity and size of the RT-PCR product.

To quantitatively assess the abundance of each of the alternate IGF-I mRNA forms for each growth plate cellular fraction, the amplification was done at low cycle number to ensure the amplification was in the exponential phase. For these analyses $100 \mathrm{ng}$ samples of total RNA or serial dilutions $\left(10^{-6}-10^{2} \mathrm{pg}\right)$ of the 395 base IGF-I cRNA standard were reverse transcribed into first strand cDNA by incubation in a $20 \mu \mathrm{l}$ reaction containing MMLVRT $1 \times$ buffer, $0.5 \mathrm{mM}$ dNTPs, $0.2 \mu \mathrm{g}$ oligo(dT) $)_{12-18}, 6$ units of RNasin and 100 units of MMLVRTase (Gibco) at $39^{\circ} \mathrm{C}$ for $60 \mathrm{~min}$, heated to $95^{\circ} \mathrm{C}$ for $10 \mathrm{~min}$ and quenched on ice. Sixty picomoles of forward primer were end-labeled with $\left[\gamma-{ }^{32} \mathrm{P}\right] \mathrm{ATP}$ $(6000 \mathrm{Ci} / \mathrm{mmol})$ (New England Nuclear, Boston, MA, USA) by T4 polynucleotide kinase (Pharmacia) and purified with a Sephadex G-25 (Sigma) spin column to remove unincorporated nucleotides. PCR was performed in a $15 \mu \mathrm{l}$ reaction containing $1 \cdot 2 \mu \mathrm{l} \mathrm{RT}$ reaction product, 4.8 pmol forward primer, $3 \mu \mathrm{l}\left(2-3 \times 10^{6}\right.$ c.p.m. $){ }^{32} \mathrm{P}$ end-labeled forward primer, 6 pmol reverse primer, $1 \times$ Thermo buffer, $2.5 \mathrm{mM} \mathrm{MgCl}_{2}, 0.2 \mathrm{mM}$ dNTPs and 0.55 unit of Taq DNA polymerase (Promega). The first strand cDNA was amplified in the exponential phase of the PCR reaction for 24 or 26 cycles $\left(94^{\circ} \mathrm{C}\right.$ for $1 \mathrm{~min}$, $62{ }^{\circ} \mathrm{C}$ for $1 \mathrm{~min}$ and $72{ }^{\circ} \mathrm{C}$ for $1 \mathrm{~min}$ ). All chondrocyte RNA samples and cRNA standards were reverse transcribed and PCR amplified in parallel tubes at the same 
time using the same master mix of reagents. To help visualize the specific PCR product, $6 \mu \mathrm{l}$ of a nonradioactive PCR product generated from a 35 cycle amplification were added to $6 \mu$ of the radioactive PCR product; this was then electrophoresed in a $2 \%$ agarose gel in the presence of ethidium bromide. Gel bands were cut out and incorporated radioactivity determined.

\section{Data analysis}

The c.p.m. in the excised gel bands from the amplification of cRNA standard were plotted against the input cRNA standard concentration by $\log -\log$ transformation. Simple regression analysis was used to determine the linear equation ( $\log$ c.p.m. $=\mathrm{a}+\mathrm{b} \times \log$ concentration) of the standard curve for each class of IGF-I mRNA. The abundance of each class of alternative IGF-I mRNA in the sample was calculated by extrapolating against the standard curve generated in that particular PCR run. The data were expressed as an absolute amount of IGF-I mRNA class (in fg) as a proportion of total RNA $(\mu \mathrm{g})$ for each cell fraction. The abundance of total IGF-I mRNA was the sum of class $1 \mathrm{Ea}, 1 \mathrm{~Eb}$ and $2 \mathrm{Ea}$ mRNA abundance. Results were expressed as the means \pm S.E.M. from three replicate chondrocyte fractionation experiments for each age group. Significance of difference was determined by Fisher's least significant difference test using SAS version 6.11 (SAS Institute Inc., Cary, NC, USA).

\section{Results}

Detection of alternative IGF-I $m R N A$ in the growth plate

Initial RT-PCR amplification using a high number of amplification cycles was carried out to determine whether the primer pairs could specifically detect the alternative IGF-I mRNA classes. The RT-PCR amplification from the growth plate RNA produced cDNA fragments of expected sizes for class $1 \mathrm{Ea}, 1 \mathrm{~Eb}$ and $2 \mathrm{Ea}$ mRNA, but not for class $2 \mathrm{~Eb}$ mRNA (Fig. 1B). This result verified the specificity of the primer pairs and demonstrated that the growth plate expressed 1Ea, 1Eb and 2Ea IGF-I mRNA. The absence of $2 \mathrm{~Eb}$ mRNA in the growth plate did not reflect a defect in the primer pair because the $2 \mathrm{~Eb}$ form was detected in mouse hepatic tissue (Lin \& Oberbauer 1998).

\section{Standard curves}

RT-PCR amplification of increasing amounts of IGF-I cRNA $\left(10^{-4}-10^{2} \mathrm{pg}\right)$ for 24 or 26 cycles directly correlated with increasing amounts of RT-PCR products as measured by the radioactivity of cut gel bands (c.p.m.). As shown in Fig. 2B, the relationship between log pg cRNA input and $\log$ c.p.m. RT-PCR output was linear for the

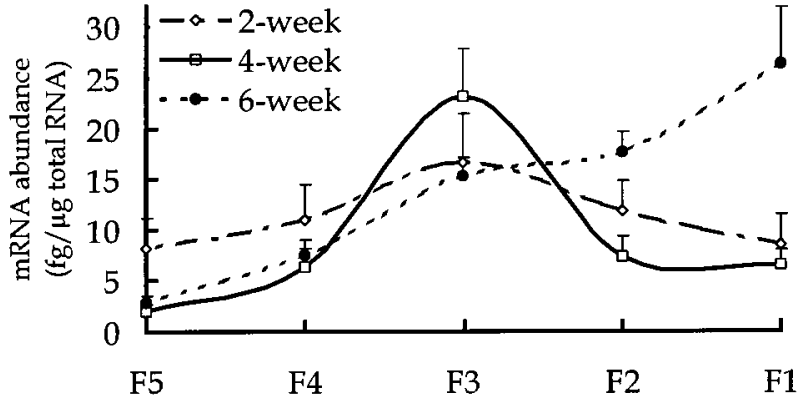

Figure 3 Total IGF-I in growth plate chondrocytes representing various stages of differentiation was calculated as a sum of class $1 \mathrm{Ea}, 1 \mathrm{~Eb}$ and $2 \mathrm{~Eb}$ mRNA as measured by quantitative RT-PCR. F1-F5 represent the fractions of chondrocytes from percoll separation. Two-week-old resting cells contained greater total IGF-I than resting cells at 4 or 6 weeks of age $(P<0 \cdot 05)$ while hypertrophic cells of 6 -week-old rats had greater IGF-I levels than those for 2- or 4-week-olds $(P<0 \cdot 05)$.

analysis of class $1 \mathrm{Ea}, 1 \mathrm{~Eb}$ or $2 \mathrm{Ea} \mathrm{mRNA}$. The expression of $2 \mathrm{~Eb}$ mRNA in growth plate chondrocytes was much lower than the linear sensitivity of the RT-PCR assay; therefore the abundance of $2 \mathrm{~Eb} \mathrm{mRNA}$ was not analyzed.

\section{Distribution patterns of alternative IGF-I $m R N A$ in the growth plate}

To study the developmental expression of alternative IGF-I mRNA in particular regions of the growth plate, the levels of each class of IGF-I mRNA were measured in percoll-fractionated chondrocytes from 2-, 4- and 6-week-old rats. Percoll fractions 5, 3 and 1 represented relatively pure populations of resting, proliferative and hypertrophic chondrocytes respectively (Oberbauer \& Peng 1995).

The expression pattern of total IGF-I mRNA (the sum of levels of IGF-I mRNA classes detected) changed from 2 to 6 weeks of age (Fig. 3). At 2 weeks, the levels of total IGF-I mRNA in resting, proliferative and hypertrophic chondrocytes were not significantly different $(P>0.05)$. At 4 weeks, the expression of total IGF-I mRNA peaked in the proliferative chondrocytes and the abundance $(23 \cdot 18 \pm 4 \cdot 67 \mathrm{fg} / \mu \mathrm{g}$ total RNA) was significantly higher than in resting and hypertrophic chondrocytes $(1.98 \pm 0.76$ and $6.46 \pm 1.47 \mathrm{fg} / \mu \mathrm{g}$ total RNA, $P<0 \cdot 05)$. At 6 weeks, the peak expression of total IGF-I mRNA shifted from proliferative chondrocytes $(15.38 \pm$ $1.83 \mathrm{fg} / \mu \mathrm{g}$ total RNA) to hypertrophic $(26.25 \pm 5 \cdot 66 \mathrm{fg} /$ $\mu \mathrm{g}$ total RNA, $P<0 \cdot 05)$. The resting chondrocytes expressed higher levels of total IGF-I mRNA at 2 weeks of age $(8.23 \pm 2.91 \mathrm{fg} / \mu \mathrm{g}$ total RNA $)$ than at 4 or 6 weeks $(1.98 \pm 0.76$ and $2.91 \pm 0.56 \mathrm{fg} / \mu \mathrm{g}$ total RNA respectively, $P<0 \cdot 05)$. The levels of total IGF-I mRNA in proliferative chondrocytes were not significantly different during the postnatal period from 2 to 6 weeks $(P>0 \cdot 05)$, 
while the hypertrophic chondrocytes expressed higher levels of total IGF-I mRNA at 6 weeks than at 2 or 4 weeks $(P<0 \cdot 05)$.

At all ages studied, 1Ea mRNA was the most abundant class expressed in the costochondral growth plate (Fig. 4). At 2 weeks of age, proliferative chondrocytes expressed significantly higher levels of 1Ea mRNA $(11.55 \pm 2.14 \mathrm{fg} / \mu \mathrm{g}$ total RNA) than the hypertrophic $(4.50 \pm 1.60 \mathrm{fg} / \mu \mathrm{g}$ total RNA $)(P<0 \cdot 05)$. At 4 weeks, this was still true: $19 \cdot 55 \pm 3 \cdot 90,0.99 \pm 0.41,1 \cdot 83 \pm$ $0.40 \mathrm{fg} / \mu \mathrm{g}$ total RNA for proliferative, resting and hypertrophic chondrocytes respectively $(P<0 \cdot 05)$. At 6 weeks, the abundance of $1 \mathrm{Ea} \mathrm{mRNA}$ in proliferative chondrocytes $(12 \cdot 47 \pm 1 \cdot 10 \mathrm{fg} / \mu \mathrm{g}$ total RNA) was significantly lower than that of hypertrophic chondrocytes $(21.24 \pm$ $3.34 \mathrm{fg} / \mu \mathrm{g}$ total RNA), but higher than that of resting chondrocytes $(1.96 \pm 0.45 \mathrm{fg} / \mu \mathrm{g}$ total RNA $)(P<0.05)$.

Class $1 \mathrm{~Eb}$ mRNA was the second most abundant class expressed in growth plate chondrocytes (Fig. 4). In 2-week-old rats, the growth plate chondrocytes expressed similar levels of $1 \mathrm{~Eb} \mathrm{mRNA}$ across the growth plate (ranging from 2.59 to $3.72 \mathrm{fg} / \mu \mathrm{g}$ total RNA). In 4-weekold rats, the level of $1 \mathrm{~Eb}$ mRNA was low in resting chondrocytes $(0 \cdot 67 \pm 0 \cdot 28 \mathrm{fg} / \mu \mathrm{g}$ total RNA $)$ and significantly higher $(P<0.05)$ in hypertrophic chondrocytes $(3 \cdot 70 \pm 0.82 \mathrm{fg} / \mu \mathrm{g}$ total RNA). In 6-week-old rats, $1 \mathrm{~Eb}$ mRNA abundance was significantly higher in hypertrophic chondrocytes $(3.96 \pm 2.01 \mathrm{fg} / \mu \mathrm{g}$ total RNA) relative to that detected for resting chondrocytes $(0.74 \pm 0.07 \mathrm{fg} / \mu \mathrm{g}$ total RNA $)(P<0.05)$.

Class 2Ea mRNA was expressed at very low levels in growth plate chondrocytes (ranging from $0 \cdot 20$ to $1.34 \mathrm{fg} / \mu \mathrm{g}$ total RNA). The levels were not significantly different across the growth plate in 2- and 6-week-old rats $(P>0.05)$, although in 4 -week-old rats, the levels of $2 \mathrm{Ea}$ mRNA in proliferative and hypertrophic chondrocytes were higher than those determined for resting chondrocytes $(P<0 \cdot 05)$.

\section{Discussion}

We have previously described a density separation method to generate cell fractions representing growth plate chondrocytes at various stages of differentiation with each fraction exhibiting morphology, proliferative rates and marker mRNA expression consistent with in vivo positional phenotypes (Oberbauer \& Peng 1995). In the present study, by applying quantitative RT-PCR analysis to fractionated chondrocytes, we showed that total IGF-I mRNA was differentially expressed in the rat growth plate.

The total IGF-I mRNA distribution within the rat growth plate was altered during the 2 to 6 week growth period. The 2 -week-old rat resting chondrocytes expressed significantly higher levels of IGF-I mRNA than
A

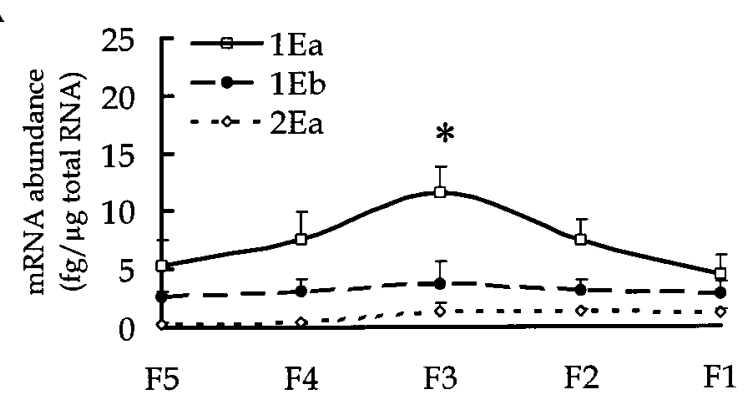

B
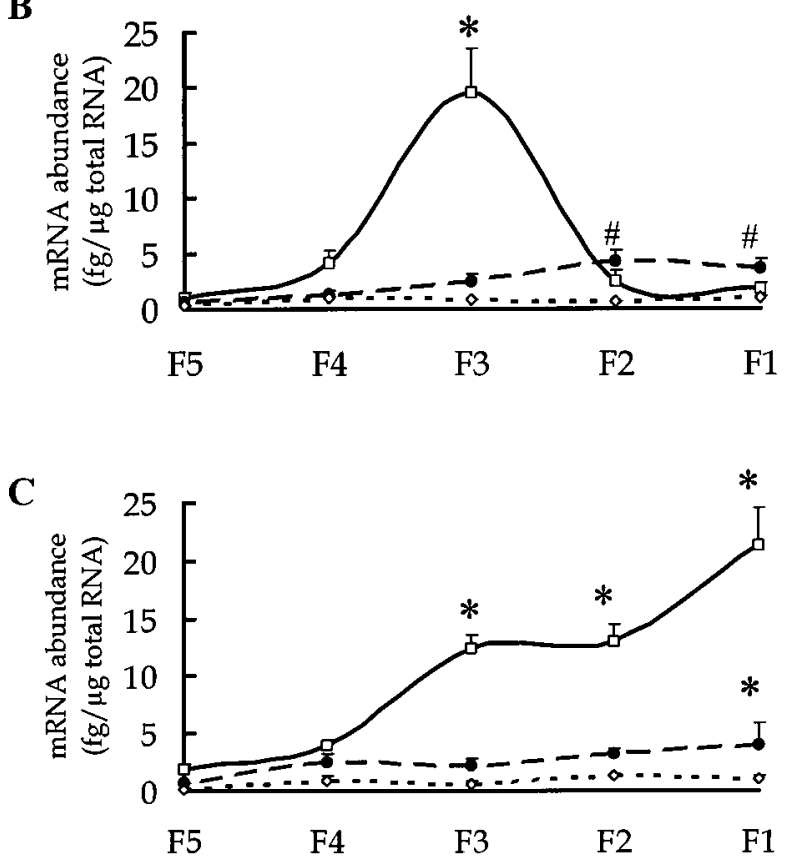

Resting Proliferative Hypertrophic

Figure 4 Expression of alternative IGF-I mRNA classes in percoll-fractionated growth plate chondrocytes representing various stages of differentiation; mRNA abundance was determined by quantitative RT-PCR. F1-F5 represent fractions 1-5 from percoll separation. (A) Cells isolated from 2-week-old rats, * designates that the $1 \mathrm{Ea}$ form was significantly elevated in proliferative fraction $3(P<0 \cdot 05)$ relative to the hypertrophic fraction 1. (B) Cells isolated from 4-week-old rats, * designates that the 1 Ea form was significantly $(P<0.05)$ elevated in proliferative fraction 3 relative to all other fractions while \# designates significantly higher $(P<0 \cdot 05)$ levels of the $1 \mathrm{~Eb}$ form relative to that of fractions 4 and 5 , resting cells. (C) Cells isolated from 6-week-old rats; * designates levels of $1 \mathrm{Ea}$ and $1 \mathrm{~Eb}$ forms significantly elevated relative to levels in the resting cells $(P<0 \cdot 05)$.

resting cells from 4- and 6-week-old rats suggesting that IGF-I may play a role in stimulating resting chondrocytes to enter the cell cycle during early postnatal development. This idea is supported by the in vivo observation that IGF-I 
treatment shortens cell cycle times in resting chondrocytes (Hunziker et al. 1994). In the 4-week-old rat, the predominant expression of IGF-I mRNA in the proliferative chondrocytes correlates with the important role of IGF-I in promoting clonal expansion (Nilsson et al. 1986, Lindahl et al. 1987), shortening cycle time and increasing cell volume of chondrocytes in the proliferative zone (Hunziker et al. 1994). Our finding that at 4 weeks of age proliferative chondrocytes expressed much higher levels of total IGF-I mRNA than resting and hypertrophic chondrocytes is in accordance with the immunolocaliztion of IGF-I to the proliferative zone reported by Nilsson et al. (1986). The increased total IGF-I mRNA expression in 6-week-old hypertrophic chondrocytes supports a role for IGF-I modulation of cellular hypertrophy by increasing cell height and cell volume at later ages (Hunziker et al. 1994). Taken together, the changes of IGF-I mRNA distribution within the growth plate confirm that IGF-I plays an important role in chondrocyte function at all stages of differentiation. Additionally, its primary site of action may shift from resting chondrocytes to proliferative chondrocytes and, further, to hypertrophic chondrocytes during the postnatal period from 2 to 6 weeks of age.

Specific IGF-I mRNA classes also exhibited temporal and spatial regulation within distinct zones of the growth plate during postnatal development. Growth plate chondrocytes expressed high levels of class $1 \mathrm{Ea}$ and $1 \mathrm{~Eb}$ mRNA, indicating that the transcription start sites on leader exon 1 were more frequently used than those on leader exon 2 in the growth plate. While the $1 \mathrm{Ea}$ class was the most prevalent, the relative abundance of $1 \mathrm{~Eb} \mathrm{mRNA}$ in resting, proliferative or hypertrophic chondrocytes of the present study $(25-30 \%, 12-22 \%$ and $15-60 \%$ of total IGF-I mRNA respectively) was much higher than that reported for extrahepatic tissues $(\sim 2-5 \%$ of total IGF-I mRNA) and the same or higher than that for liver $(13 \%$ of total IGF-I mRNA as reported by Lowe et al. (1988)). As $\mathrm{GH}$ is known to regulate total IGF-I mRNA in the rat growth plate (Isgaard et al. 1988, Nilsson et al. 1990) and can increase both class 1 and class 2 mRNA abundance (Lowe et al. 1987, Lin \& Oberbauer 1998) while promoting the inclusion of exon 5 (Lowe et al. 1988), the abundance of the exon 1-containing transcripts and the significant expression of $1 \mathrm{~Eb} \mathrm{mRNA}$ in growth plate chondrocytes may represent preferential upregulation of exon 1- and exon 5-containing IGF-I mRNA transcripts in growth plate chondrocytes by $\mathrm{GH}$.

In the growth plate, as in bone (West et al. 1996), class 1 transcripts were the major contributors to total IGF-I mRNA. The mechanism by which the distribution pattern of alternative IGF-I mRNA is regulated during this postnatal period is not clear. It is known, however, that GH increases total IGF-I mRNA and immunoreactivity in the growth plate of the hypophysectomized rat (Nilsson et al. 1986, Isgaard et al. 1988) and regulates the choice of IGF-I transcription initiation (Foyt et al.
1992). In the present study, we observed that hypertrophic chondrocytes expressed higher levels of total IGF-I mRNA in later development (4- to 6-week-old rats). At these ages, GH receptor mRNA is more abundant in mature hypertrophic chondrocytes (Oberbauer \& Peng 1995). We suggest that the shift of IGF-I mRNA expression from proliferative to hypertrophic chondrocytes from 4 to 6 weeks of age is mediated by GH to increase the degree of chondrocyte hypertrophy and facilitate bone formation.

\section{Acknowledgements}

We would like to thank Raymond Peng for his technical advice in growth plate chondrocyte isolation. This work was supported by USDA-NRICGP grant 92-37206-7915.

\section{References}

Adamo ML, Lowe WL Jr, LeRoith D \& Roberts CT Jr 1989 Insulin-like growth factor I messenger ribonucleic acids with alternative $5^{\prime}$-untranslated regions are differentially expressed during development of the rat. Endocrinology 124 2737-2744.

Adamo ML, Ben-hur H, LeRoith D \& Roberts CT Jr 1991 Transcription initiation in the two leader exons of the rat IGF-I gene occurs from disperse versus localized sites. Biochemical and Biophysical Research Communications 176 887-893.

Arkins S, Rebeiz N, Biragyn A, Reese DL \& Kelly KW 1993 Murine macrophages express abundant insulin-like growth factor I class 1 Ea and Eb transcripts. Endocrinology 133 2334-2342.

Bucci C, Mallucci P, Roberts CT Jr, Frunzio R \& Bruni CB 1989 Nucleotide sequence of a genomic fragment of the rat IGF-I gene spanning an alternate $5^{\prime}$ noncoding exon. Nucleic Acids Research 9 3596.

Chomczynski P \& Sacchi N 1987 Single-step method of RNA isolation by acid guanidinium thiocyanate-phenol-chloroform extraction. Analytical Biochemistry 162 156-159.

Daughaday WH \& Rotwein P 1989 Insulin-like growth factors I and II. Peptide, messenger ribonucleic acid and gene structures, serum, and tissue concentrations. Endocrine Reviews 10 68-91.

Foyt HL, Lanau F, Woloschak M, LeRoith D \& Roberts CT Jr 1992 Effect of growth hormone on levels of differentially processed insulin-like growth factor I mRNAs in total and polysomal mRNA populations. Molecular Endocrinology 6 1881-1888.

Hall LJ, Kajimoto Y, Bichell K, Kim SW, James PL, Counts D, Nixon LJ, Tobin G \& Rotwein P 1992 Functional analysis of the rat insulin-like growth factor I gene and identification of an IGF-I gene promoter. DNA and Cell Biology 11 301-331.

Heuvel JPV, Tyson FL \& Bell DA 1993 Construction of recombinant RNA templates for use as internal standards in quantitative RT-PCR. Biotechniques 14 395-398.

Holthuizen E, LeRoith D, Lund PK, Roberts CT Jr, Rotwein P, Spencer EM \& Sussenbach JS 1991 Revised nomenclature for the insulin-like growth factor genes and transcripts. In Modern Concepts of Insulin-like Growth Factors, pp 733-736. Ed. EM Spencer. New York: Elsevier Publishing Co.

Horton RM, Hunt HD, Ho SN, Pullen JK \& Pease LR 1989 Engineering hybrid genes without the use of restriction enzymes: gene splicing by overlap extension. Gene 77 61-68.

Hunziker EB \& Schenk RK 1989 Physiological mechanisms adopted by chondrocytes in regulating longitudinal bone growth in rats. Journal of Physiology 414 55-71. 
Hunziker EB, Wagner J \& Zapf J 1994 Differential effects of insulinlike growth factor I and growth hormone on developmental stages of rat growth plate chondrocytes in vivo. Journal of Clinical Investigation 93 1078-1086.

Isaksson OGP, Lindahl A, Nilsson A \& Isgaard J 1987 Cellular mechanism(s) for the stimulatory effect of growth hormone on longitudinal bone growth. In Growth Hormone. Basic and Clinical Aspects, pp 307-319 Eds OGP Isaksson, C Binder, K Hall \& B Hökfelt. Amsterdam: Excerpta Medica.

Isaksson OGP, Nilsson A, Isgaard J \& Lindahl A 1990 Cartilage as a target tissue for growth hormone and insulin-like growth factor-I. Acta Paediatrica 367 (Suppl) 137-141.

Isgaard J, Möller C, Isaksson OGP, Nilsson A, Mathews LS \& Norstedt G 1988 Regulation of insulin-like growth factor messenger ribonucleic acid in rat growth plate by growth hormone. Endocrinology 122 1515-1520.

Kember NF 1993 Cell kinetics and the control of bone growth. Acta Paediatrica 391 (Suppl) 61-65.

Lindahl A, Isgaard J, Carlsson L \& Isaksson OGP 1987 Differential effects of growth hormone and insulin-like growth factor I on colony formation of epiphyseal chondrocytes in suspension culture in rats of different ages. Endocrinology 121 1061-1069.

Lin W-w \& Oberbauer AM 1998 Alternative splicing of insulin-like growth factor I mRNA is developmentally regulated in the rat and mouse with preferential exon 2 usage in the mouse. Growth Hormone and IGF Research 8 225-233.

Lowe WL Jr, Roberts CT Jr, Lasky SR \& LeRoith D 1987 Differential expression of alternative $5^{\prime}$ untranslated regions in mRNAs encoding rat insulin-like growth factor I. Proceedings of the National Academy of Sciences of the USA 84 8946-8950.

Lowe WL Jr, Lasky SR, LeRoith D \& Roberts CT Jr 1988 Distribution and regulation of rat insulin-like growth factor I messenger ribonucleic acids encoding alternative carboxyterminal E-peptides: evidence for differential processing and regulation in liver. Molecular Endocrinology 2 528-535.

Nilsson A, Isgaard J, Lindahl A, Dahlstrom A, Skottner A \& Isaksson OGP 1986 Regulation by growth hormone of number of chondrocytes containing IGF-I in rat growth plate. Science $\mathbf{2 3 3}$ 571-574.

Nilsson A, Carlsson B, Isgaard OGP \& Rymo L 1990 Regulation by $\mathrm{GH}$ of insulin-like growth factor-I mRNA expression in rat epiphysial growth plate as studied with in situ hybridization. Journal of Endocrinology 125 67-74.

Oberbauer AM \& Peng R 1995 Fractionation of growth plate chondrocytes: differential expression of IGF-I and growth hormone and IGF-I receptor mRNA in purified populations. Connective Tissue Research 31 179-187.

Ohlsson C, Isgaard J, Törnell J, Nilsson A, Isaksson OGP \& Lindahl A 1993 Endocrine regulation of longitudinal bone growth. Acta Paediatrica (Suppl) 391 33-40.

Shimatsu A \& Rotwein P 1987 Mosaic evolution of the insulin-like growth factors. Journal of Biological Chemistry 262 7894-7900.

Wang AM, Doyle MV \& Mark DF 1989 Quantitation of mRNA by the polymerase chain reaction. Proceedings of the National Academy of Sciences of the USA 86 9717-9721.

West CA, Arnett TR \& Farrow SM 1996 Expression of insulin-like growth factor I (IGF-I) mRNA variants in rat bone. Bone 19 $41-46$.

Received 30 July 1998

Accepted 2 November 1998 